\title{
AN EFFECTIVE INTEREST ALIGNMENT MECHANISM OR A TOOL TO EXPROPRIATE: A REVIEW OF MALAYSIAN ESOS ADOPTION
}

\author{
ZAHIRUDDIN GHAZALI \\ Faculty of Finance and Banking \\ Universiti Utara Malaysia \\ FAUZIAH MD. TAIB \\ School of Management \\ Universiti Sains Malaysia
}

\begin{abstract}
Employee Shares Option Scheme (ESOS) is theorised as a solution to bridge the interest of managers with owners of the firms particularly in setting where ownership is widely held. Modern corporations in developing countries are characterised by controlling shareholders who are also actively involved in the management of firms. The resultant conflict of interests between the majority and the minority shareholders questions the suitability of ESOS in aligning their interests towards the firm's common goal. Findings from the study suggest that the usual determinants of ESOS adoption in the West do not hold in the environment of high ownership concentration. The post-adoption performance has not improved and there is no significant difference between the adopting and the non-adopting firms after controlling for size and industry. Nonetheless, there is evidence of better performance for adopting firms in terms of profitability albeit very weak in magnitude.
\end{abstract}

Keywords: Employee Shares Option Scheme (ESOS), Interest Alignment, Agency Problems, Post-Adoption Performance.

\section{Introduction}

The introduction of a modern corporation has marked a new era in managing business. Owners no longer manage the business themselves, instead hiring professional managers to do so on their behalf. Whilst the philosophy helps to overcome the lack of competency to manage firms, it has at the same time brought with it a new set of problems (agency problems).
Agency problems arise when one party (managers) has more knowledge than the others and whose behaviour cannot be directly observed or monitored at all times. As Jensen \& Meckling (1976) point out, professional managers have the incentives to take on decisions that may not be in the best interest of the owners but may well be maximizing the utility of the decision-makers (managers). One of the ways to converge the managers' interest with that of the owners is by introducing Employees Stock Options 
Scheme (ESOS). Since the value of ESOS is a function of the prevailing firm's share price, managers have incentives to take on positive net present value projects, minimise shirking behaviours and start aligning their interest with the owners' to maximise the firm's value. By making managers part of the owners, they will ensure that the objective of the firm is met.

Although ESOS is fast gaining popularity as the converging tool, the appropriate use of ESOS has been questioned. In Malaysia, prior to $9^{\text {th }}$ February 2004, ESOS was - governed under Schedule 1 of the Securities Commission Act 1993 (SCA) through Guidance Notes $8 \mathrm{~B}$ and $9 \mathrm{~A}$. The process starts with an application by the firm's through its Board of Directors after being endorsed by the firm shareholders. ESOS are then granted to intended recipients upon approval from the Securities Commission (SC) with the amount to each recipient usually vetted by the firm's remuneration committee. After this period, ESOS is solely governed by the firm's ESOS Guidelines or Charter. In an environment where the firm's ownership is dispersed, the use of ESOS is logical as it is expected to bring together the interests of the owners and the managers. However, firms with high ownership concentration where agency problem exists between the majority shareholders and the minority shareholders, the use of ESOS would only exacerbate the situation. In emerging markets the occurrence of controlling shareholders or their family members managing the firm is also quite widespread. As such, the adoption of ESOS would not align the interest but could be used as a tool to expropriate wealth instead. With this conjecture as a background, this study is set to find evidence to see if the above proposition is substantiated.

Findings from the study suggest that the usual determinants of ESOS adoption in the
West do not hold in the environment of high ownership concentration. The post-adoption performance has not improved and there is no significant difference between the adopting and the non-adopting firms after controlling for size and industry. Nonetheless, there is evidence of better performance for adopting firms in terms of profitability albeit very weak in magnitude.

The immediate section reviews all the relevant literature before a research methodology is proposed next to capture the intended effect. This is followed by the findings and a discussion of the study before a conclusion is offered.

\section{Literature Review}

Conceptually, there are two (2) types of agency problem faced by firms around the world. The first type of agency problem is between the principals and the agents and is known as type I problem. This type of agency problem is more prevalent in countries where ownership is rather dispersed. In contrast, type II agency problem exists between the majority and the minority shareholders, where there is high ownership concentration among firms. While the former condition (dispersed ownership) is common among the developed countries the latter type of problem is unique to the emerging markets or developing countries (Claessens, Djankov, \& Lang, 2000; Haniffa \& Hudaib, 2006; Khatri, Leruth, \& Piesse, 2002; Mitton, 2002).

Theoretically ESOS should serve as an interest alignment tool to converge the managers' interest in line with the owners', particularly for type I agency problem. For a country like Malaysia whose ownership pattern is reported to be highly concentrated 
(Capulong, Edwards, Webb, \& Zhuang, 2000), the use of ESOS or ESOP is highly questionable. High ownership concentration induces type II not type I agency problem. Hence, the use of ESOS or ESOP is not likely to solve the misalignment problem. Giving ESOS or ESOP to controlling shareholders who are typically involved in the running of the business will not help to solve the convergence of interest as there is no asymmetric information problem except between the controlling (majority) and the minority shareholders. The act of adopting ESOS or ESOP could very well signal that wealth expropriation is taking place.

Evidence from the developed countries lends some support to ESOS being the alignment tool, albeit weakly. Yermack (1995) provides a comprehensive study on the determinants of ESOP (Employees Share Option Plan) for American firms based on the agency and financial contracting theory and finds only weak supports for the relationship between agency cost reductions and ESOP. Matsunaga (1995), also an American-based study on the effectiveness of ESOS to curb agency cost, on the other hand, reports that the lower the value of reported income relative to a target level, the greater the value of ESOP per employee issued. This shows that firms do value ESOS / ESOP as an interest alignment catalyst to achieve their financial goals. In contrast, Hartzell and Starks (2003) find that institutional investors do not favour ESOS adoption as revealed by a negative relation between institutional-investor concentrations to the level of executive compensation especially share option grants.

Evidence from the emerging market as depicted by Ding and Sun (2001) study indicates that in Singapore the value of ESOP is positively associated with the firms' growth opportunities but negatively related to debt servicing capacity. While high-growth opportunity firms need to retain the key employees in the company, this is an offset by the probability of violating debt covenants that could bring negative consequences. Since ESOS / ESOP literature from emerging markets is sparse, its effectiveness has not been thoroughly evaluated.

The Malaysian corporate sector is characterized by an insider system of corporate governance where in certain firms, high levels ownership concentration, cross holdings and significant participation of owners in management are apparent (Claessens, Djankov, \& Lang, 2000; Lemmons \& Lins, 2001; Mitton, 2002).

A review of prior studies suggests that most studies on ESOS post performance in developed markets have short-term positive accounting and financial outcomes. Some studies report no association while most of the earlier studies document significant positive association between ESOS adoption and improved performance (Lewellen \& Huntsman, 1970); Coughlan \& Schmidt, 1985; Murphy, 1985). Recent literature [such as Core and Guay (2001), Core and Larcker (2002), Himmelberg, Hubbard and Palia (1999), Ittner et al. (2003)] however, report mixed results that fuel the current debate further.

The above discussion thus far has questioned whether ESOS or ESOP is effective as a mechanism to mitigate agency problems or it is just another tool of wealth expropriation. The answer to this question is crucial as the implications or consequences of these findings are far-reaching. ESOS or ESOP is considered effective if it meets the intended objectives which include changes in size, changes in leverage, higher growth and 
income above its target level. This includes improvement in the firms' performance after ESOS adoption. Conversely, ESOS is only a tool of wealth expropriation if the usual determinants of ESOS adoption are not met and the post-adoption performance has not improved.

Table 1

First Time ESOS Adopters 1989 - 2001

\begin{tabular}{|c|c|c|}
\hline & Frequency & Percent \\
\hline 1989 & 9 & 4.21 \\
\hline 1990 & 11 & 5.14 \\
\hline 1991 & 13 & 6.07 \\
\hline 1992 & 10 & 4.67 \\
\hline 1993 & 16 & 7.48 \\
\hline 1994 & 4 & 1.87 \\
\hline 1995 & 6 & 2.8 \\
\hline 1996 & 12 & 5.16 \\
\hline 1997 & 4 & 1.87 \\
\hline 1998 & 2 & 0.93 \\
\hline 1999 & 13 & 6.07 \\
\hline 2000 & 41 & 19.16 \\
\hline 2001 & 17 & 7.94 \\
\hline 2002 & 28 & 13.08 \\
\hline 2003 & 14 & 6.54 \\
\hline 2004 & 20 & 9.35 \\
\hline Total & 214 & 100.0 \\
\hline
\end{tabular}

\section{Methodology}

\section{Data and Sample Selection}

This study covers an observation period from 1st January 1989 to 31st December 2004. It is believed that 16 -year period would encompass various Malaysian economic and financial market scenarios of stable (1989-1992), boom (1993-1996), decline (1997-1998), recovery (1999-2001) and stable (2002-2004) periods. Moreover, this study limits its observation to events no earlier than 1989 due to the unavailability of data. Furthermore, this study also limits its observation window events in ESOS post performance to no later than 31 st December 2004 due to the limitations of post- performance analysis. This study requires that each firm has at least three 
(3) years post-adoption performance data to ascertain the impact of ESOS adoption. For simplicity, the study uses ESOS or ESOP interchangeably. Table 1 displays the number of firms issuing ESOS for the first time throughout the study period.

This study includes all listed firms in the Malaysian Bourse regardless of its trading board. However, for financial and insurance companies, and companies trading in other than Malaysian Ringgit domicile are excluded from the initial sample due to different regulatory environments and difficulties in assessing the exchange rate. Initially 277 firms that had adopted the executive's share option were identified during the study period. However, this figure was reduced to 214 as 62 firms were excluded due to delisting, mergers and acquisitions, regulatory and currencies differences, unavailability of data, and no suitable matched firms.

In order to see the impact of ESOS adoption on firms' performance, we used the match pair methodology similar to the one used by Teoh, Welch and Wong (1998). To avoid size and industry bias, the non-adopting firms are to be at least 75 per cent of the asset-scale and within the same industrial sector. Table 2 summarises the sample selection for the study.

\section{Table 2}

\section{Sample Selection}

First time ESOS adopters from $1^{\text {st }}$ Jan $1989-31^{\text {st }}$ Dec 2004

277

Less:

Financial and insurance firms

8

Delisting

Foreign domicile

Untraceable and unavailability of data

Matched firms unavailable

Total number of ESOS non-adopter in the sample

428

\section{Source of Data}

All financial information in this study is based on the Malaysian Bourse (MB) Annual Handbook and the respective firms' annual reports. As suggested by Suret, Morill and Morill (1997) should there be any discrepancies between the two data sources the latest data from the firms' annual reports will take precedence. 
Initially, ESOS adopted firms were detected using the MB-owned monthly publication 'Investor Digest'. Nonetheless, further detection was made using the MB web informationunder 'ChangeinShareholdings', and 'Circular to Shareholders' of respective firms. This action was necessary due to changes in the publication content, which eliminate 'Company's announcements' on ESOS adoption post-1999 period.

\section{Determinants of ESOS Adoption}

- This study employs the uses the logit regression model to test the hypotheses built. The logit analysis is used when the linear probability model is unable or not suitable to describe the pattern of the data. The linear probability can be written as;

$y_{i}=\beta X_{i}+u_{i} \quad$ with $\mathrm{E}($ ui) $=0 \quad$ (eq. 1$)$

where $X_{i}$ is the vector of explanatory variables, $\beta$ is the vector of unknown parameters and $u i$ is the random error. The conditional expectation $E(y i \mid \mathrm{X} i)$ is equal to $\beta^{\prime} X_{i}$. It can be interpreted as the probabilities that the event will occur given $\mathrm{X}$ conditions. The difference between the linear probability model and the logit model is that in the logit model $\beta^{\prime} X_{i}$ is not $E\left(y i \mid X_{i}\right)$ but it is $E\left(y i^{*} \mid \mathrm{X}_{i}\right)$ where $y i^{*}$ is the unobserved variable. The logit model usually solves this by using the maximum like lihood method. Moreover, the logit model does not assume multivariate normality or equality in variance covariance matrices as in discriminant analysis. Therefore, it is expect that the model should perform better than the discriminant analysis. In the logit model, it is assumed that there is an underlying response variable $y i^{*}$ defined by the regression relationship,

$$
y^{*}{ }_{i}=\beta X_{i}+u_{i}
$$

where $\beta$ is a vector of unknown parameters, $X_{i}$ is a vector of predictors for the $i$ th observation and $u i$ are independent and identically distributed random variables with mean $=0$. The observed variable, $y$, is related to $y i^{*}$ through the relation:

$y=1 \quad$ if $y i^{*}>0$ and

$y=0 \quad$ otherwise.

If $u$ is to have a logistic distribution, then a logit model is produced. The likelihood function for the logit model is given by:

$$
L=\prod_{y=0} F\left(-\beta^{\prime} X_{i}\right) \prod_{y i=1}\left[1-F\left(-\beta^{\prime} X_{i}\right)\right]
$$

where $\mathrm{F}($.$) is the distribution of \mathrm{u}$. For the logit model, $\mathrm{F}\left(-\beta^{\prime} X_{i}\right)$ is simplified:

$$
F\left(-\beta^{\prime} X_{i}\right)=\frac{1}{1+\exp \left(\beta^{\prime} X_{i}\right)} .
$$

Hence $\mathrm{F}$ has a close form expression as it does not involve integrals explicitly. The model can also be written as:

$$
\operatorname{Pr}=\frac{1}{1+\exp (-Z)}
$$

where $\mathrm{Z}$ is the linear combination of $\beta$, which is the coefficient estimated from the data, and $\mathrm{X}$, which is the independent variable,

$Z=\beta_{0}+\beta_{1} X_{1}+\beta_{2} X_{2}+\ldots+\beta_{p} X_{p}$.

The use of this model is an adaptation of a similar model used by Ding and Sun (2001) that simplifies Matsunaga's (1995) model. The model is as follows:

Original model,

$V_{i t}=b_{0}+b_{1} \ln (T A)+b_{2} D / E+b_{3} M B R+b_{4} I N C+b_{5} M S H+$ $b_{6} I D V S H+b_{7} I N S S H+b_{8} G L C+e$

Since a match pair is used, where size is controlled, this study proposes,

$$
\begin{aligned}
& V_{i t}=b_{0}+b_{1} \operatorname{ChgT} / A_{-1,0}+b_{2} \operatorname{ChgDE}_{-1,0}+b_{3} \text { Tobins_ } Q+\text {. } \\
& b_{4} M S H+b_{5} I D V S H+b_{6} I N S S H+b_{7} G L C S H+b_{8} I O T+ \\
& b_{9} D u m F+e
\end{aligned}
$$


where dependent variable $\mathrm{V}_{i t}$ is $=1$ for adopting firms and $=0$ for non-adopting firms, which is a categorical data, thus, the use of logistic regression is deemed suitable. Logistic regressions are used to differentiate characteristics between those of adopting and non- adopting firms. Furthermore, the logistic approach (model) does not assume multivariate normality or equality in variance matrices as in discriminant analysis.

Although the present methodology leaves size out of the model, change in TA (Total Assets) is still included to capture changes in a firm's size that may trigger adoption of ESOS. Similarly, change in the Debt Equity ratio is introduced for the same reason. It is believed that changes in financial performance rather than current performance would provide better understanding of the 'push' factor in adopting the scheme.

While Ding \& Sun (2001) uses MBR (market-to-book ratio) as proxy of growth, this study makes use of the approximate Tobin's Q as a proxy for growth. Tobin's Q is defined as the market value of assets divided by the book value of the assets (BVA). Market value of the asset is measured as the sum of market value of the equity (MVE) measured at the fiscal year-end plus the book value of liabilities (BVL).

$$
\text { Tobin's_Q } Q=\frac{M V E+B V L}{B V A} .
$$

Furthermore, income over target (IOT) measures the extent of the firms' income that is higher than its target level:

IOT $=($ Income - Target $)$;

if Income $>$ Target, otherwise, $\mathrm{INC}=0$

Income is the net income of the firm for the year and Target is set based on the previous year's income. The logic behind this definition of Target is to benchmark the income against some adaptive expectation that is not below the previous year's income with allowance for growth (Ding \& Sun, 2001).

Target $=$ Income $_{t-1}+\left(\right.$ Income $_{t-1}-$ Income $\left._{t-3}\right) / 3$; if Incomet-1 > Incomet-3, Target=Incomet-1

The family-owned firms (DumF) variable is added into the model to provide a better picture of the Malaysian corporate scenario. Although this variable is rarely seen in developed market-based models, Claessens et al. (2002) and Khatri et al. (1999) have purported that family influence is evident in the Malaysian corporate culture. In this study, a firm is considered as a family-owned firm if a family's shareholding (directly or indirectly owned, or combined) is more than 50 per cent with at least two (2) persons from the same family (immediate or intermediate) sitting in the firm's board of directors.

Each of the ownership variables (managerial, individual, institutional, and government ownership) is denoted using cumulative percentages. Institutional ownership refers to the share owned by other firms including banks, insurance, and trust fund companies. Moreover, government-linked companies (GLCs) are differentiated from other institutional blockholders due to investment preferences. In this study, $b_{o}$ is a constant; $b_{1}$ to $b_{10}$ are the coefficients corresponding to the independent variables; and $e$ is a Gaussian residual term.

\section{ESOS Adoption and Firms Post Performance}

If the idea of ESOS adoption is converging the interest of the managers and the shareholders, the firms' performance after the adoption of ESOS should improve. To 
facilitate the comparison, firms' performance is not just compared against itself but also against a match-pair firm which resembles the adopting firm in terms of size and industry as explained earlier.

Several financial ratios are analysed to measure the various aspects of performance. The indicators (ratio) selected for this purpose include: operating income to sales [operating-profit margins (OPM)]; net income to sales [net-profit margin (NPM)]; net income to total asset [return on assets (ROA)]; net income to total equity [return on equity (ROE)]; Tobin's Q; and debt to asset ratio (D/A). These variables are similarly used by other ESOS-based studies by Jain \& Kini (1994), Pugh, Oswald \& Jahera (2000) and Yeo, Chen, Ho \& Lee (1999). While the first four ratios are focused on profitability and operating performances, D/A is a proxy for leverage, and Tobin's Q is for growth. As for the years (unless noted, all years are fiscal years) following and including the ESOS adoption, each ratio is compared to its corresponding value at the end of the year before the ESOS adoption (referred to as the base year). The base year is noted as year -1 , the year of ESOS adoption is year 0 , and so on and so forth. Therefore, an $(-1,0)$ event window presents the change in the financial ratio from the end of year -1 to the end of year 0 ; thus, the change in the ratio is concurrent with ESOS adoption. Changes are tested for up to three years after the adoption as a longer event window will produce fewer observations.

Change is calculated as ,

$$
\frac{P T_{t}-P T_{-1}}{P T_{-1}} \text {, and } \frac{P C_{t}-P C_{-1}}{P C_{-1}}
$$

where PT refers to the relevant ratios for the ESOS firm and PC refers to the corresponding ratio for tindustry control. If ESOS had no effect, then one would expect the change in the ESOS firm ratio to be no different, on the average, from the change in the overall industry.

The growth in these measures is able to provide some explanations for the change in the performance experienced by the ESOS adopted firms during the first few years after the adoption of the scheme. Tests are based on two-tailed Wilcoxon Signed Rank test, a non-parametric alternative to pairedsamples $t$ test. This test, as well as other standard parametric tests, assumes that the observations are independent. Moreover, Yeo et al. (1999) pointed out that Barber \& Lyon (1996) have shown that this method performs better than the t-test in detecting abnormal performance.

\section{Findings and Discussion}

\section{Determinants of ESOS Adoption}

We first report the size of the two groups (adopting and non-adopting firms) to ensure that they are more or less homogeneous within the acceptable range. Panel A of Table 3 shows that the firms' size between the two groups are almost similar.

To casually see the differences of the two groups based on other independent variables, the same test (matched pair t-test) was rerun. Results, as displayed in Panel B of Table 3 , indicate that the two groups differ particularly in terms of changes in firm size and level of managerial shareholdings. Under both variables, the adopters have a higher mean than the non-adopting firms. At the surface (first level of analysis), the results do indicate as though ESOS has been used for the right reasons (to improve efficiency). 
Table 3

Descriptive Matched-Paired Samples Statistics between ESOS Adopters and Non-Adopters

\begin{tabular}{lcccc}
\hline & $\begin{array}{c}\text { Adopters } \\
\text { Mean }\end{array}$ & $\begin{array}{c}\text { Non-adopters } \\
\text { Mean }\end{array}$ & t & $\begin{array}{c}\text { Sig. } \\
\text { (2-tailed) }\end{array}$ \\
\hline Panel A \\
Firm Size (lg TA) & 12.43 & 12.44 & -.57 & .57 \\
Panel B & & & & \\
$\begin{array}{l}\text { Change in Total Asset -1,0 } \\
\text { (Chg TA 1/0) }\end{array}$ & .18 & .09 & 3.48 & .00 \\
$\begin{array}{l}\text { Change in Debt Equity Ratio -1,0 } \\
\text { (Chg DE 1/ 0) }\end{array}$ & .00 & -.05 & .80 & .42 \\
Growth Proxy (Tobins Q) & 1.03 & 1.03 & .65 & .52 \\
$\begin{array}{l}\text { Managerial Shareholdings (MSH) } \\
\text { Individual Shareholdings (IDVSH) }\end{array}$ & .15 & .12 & 2.14 & .03 \\
Institutional Shareholdings (INSSH) & .53 & .20 & -1.15 & .25 \\
$\begin{array}{l}\text { Government-linked Companies } \\
\text { Shareholdings (GLCSH) }\end{array}$ & .11 & .55 & -.68 & .50 \\
\hline
\end{tabular}

We ran logistic regressions on equation 8 and the result is as displayed in Table 4. Recall that one of the main objectives of this paper is to find evidence to see if ESOS is used for efficiency reasons and thus help mitigate the agency problems. ESOS adoption is to act as a catalyst to firms' improved performance in terms of changes in size, changes in leverage, higher growth and to strive for income above their target level.

Results in Table 4 yield interesting stories when three variables are found to be significant in explaining the decision to issue ESOS when size is kept the same. Changes in total asset (Chg_TA_1_0), income over target (IOT), and familyowned firms (DumF) are able to explain
$19 \%$ of the decision to issue ESOS. This model is significant with at least $99 \%$ confidence level and has a pseudo $\mathrm{R}^{2}$ of 0.19 . Although the explanatory power is not huge, it does indicate that the model is able to explain $19 \%$ of the ESOS-adoption decision. Moreover, it is not the focus of this study to predict which factors are important in ESOS adoption but rather to see if the reasons behind the adoption do follow what the theory suggests.

Firm's size growth appears to be an important 'push' factor to adopt ESOS. This variable is adopted from Parthasarathy et al. (2006) with the intention to capture not only firm's size (this has been controlled in this study) but also to incorporate transformation in firm's 
asset size. Descriptive statistics in Table 3 confirm that ESOS-adopting firms have almost double the growth rate compared to that of the non-adopters. This rapid growth if left unchecked could pose a threat for a possible moral hazard problem as claimed by Choe (1999), who suggests that agents forsake the firms' best interest for their own due to the abundance of assets. Therefore, one way of interpreting the results would be that the shareholders are taking proactive measures (by adopting ESOS) to ensure the executives' (agents) future actions are for the firms' best interest.

However, the above finding could also be interpreted differently as there is a possibility of managing the accounting figures to justify the decision to issue or adopt ESOS. The sudden growth of firm-size over a short period (between a year after adoption and the adoption year) does raise concern if such numbers are orchestrated given a long process of ESOS adoption. There are at least four (4) phases of ESOS adoption including: (a) initiating idea (first intention to introduce ESOS), (b) the planning phase, (c) endorsement by shareholders usually in the Annual General Meeting (AGM), and (d) approval from the Securities Commission. Each phase would roughly take about a year. Combining all the phases, the whole process of ESOS adoption could take between 3 to 4 years from the inception of the idea to the adoption of ESOS. Given the time spent, the growth of firm-size could have been 'planned' so that it shows to justify the decision to adopt ESOS.

Table 4

Determinants of ESOS Adoption

\begin{tabular}{lcccc}
\hline \multicolumn{1}{r}{ Variables } & Predicted Sign & Beta Coefficient & Std.Error & Sig. \\
\hline Chg_TA_1__0 & + & $\mathbf{2 . 5 1}$ & $\mathbf{0 . 6 2}$ & $\mathbf{0 . 0 0}$ \\
Chg_DE1_0 & \pm & -0.17 & 0.22 & 0.45 \\
Tobins_Q & + & 7.21 & 5.37 & 0.18 \\
MSH & - & -0.53 & 2.01 & 0.79 \\
IDVSH & - & -2.36 & 1.98 & 0.23 \\
INSSH & - & -1.31 & 1.88 & 0.49 \\
GLCSH & + & -0.31 & 1.96 & 0.87 \\
IOT & + & $\mathbf{- 0 . 6 5}$ & $\mathbf{0 . 2 5}$ & $\mathbf{0 . 0 1}$ \\
DumF & + & $\mathbf{1 . 3 1}$ & $\mathbf{0 . 2 6}$ & $\mathbf{0 . 0 0}$ \\
Constant & & -6.94 & 5.84 & 0.24 \\
-2 Log likelihood & & & & \\
Sig. & & & & \\
Nagelkerke R Square & & & & \\
\hline
\end{tabular}


Recall that the objective of adopting ESOS is to act as a 'push factor' for firms below their target incomes to meet the specified level of income (Ding \& Sun, 2001). However, the result of this study suggests otherwise. Firms which are already achieving their target incomes are the ones eager to adopt ESOS. Implicitly, the finding suggests that ESOS is not being issued to 'push' managers to work harder i.e. to increase profitability. The lower the extent of income compared to that of the target (last year is income or the average of the last three years' income) the more is the likelihood of adopting ESOS. This evidence shows that ESOS is not being used to mitigate agency problems .

Another potential explanation is that managers are taking advantage of the lower share price as a result of having lower income to exercise their rights to buy the firm's share at discounted prices. Since managers have more information about the future well-being of the firm than the shareholders, they would be able to cash in their ESOS when good news is released in future. The setting is convenient for the managers if the shareholders buy the idea that ESOS is being issued to align the interest of the managers and the shareholders (or between the majority and the minority shareholders) but in reality is it just another means of siphoning wealth from the firm.

The practice of issuing ESOS is more prevalent among the family-owned firms than any other types of firms. Indirectly this evidence supports the contention made by Claessens et al. (2002), Khatri et al. (2002) and Lim (1981) that the presence of familyowned firms could pose interference or bring about conflict of interests in the firms' management. This is made possible as owners of family-owned firms would normally sit or have their proxies in the board of directors and make decisions that would ultimately benefit them. ESOS adoption is one of the many instances of where such conflict of interests could happen. Anecdotal evidence suggest a that ESOS is typically awarded to executives who are related (or with extended family ties) to the firm's controlling or dominating shareholders to preserve/gain wealth within/for the family.

\section{ESOS Adoption and Firms Post Performance}

Post performance of ESOS adopting firms should improve if ESOS has been effective in aligning the interest of the managers and the shareholders (or between the majority and the minority shareholders). Each adopting firm's performance is compared against its equivalent performance in the base year (one year before the adoption). Of the six measures that are chosen to measure various aspects of performance only return on assets (ROA) is found to be significant. However, the result is opposite to what is expected. Instead of improving in terms of return on assets over the three years after the adoption, the adopting firms' performances are deteriorating as evidenced by the negative values in Table 5.

The rest of the performance measures do not indicate any improvement over the three post-adoption years. It is premature to conclude at this stage that ESOS adoption does not result in better performance as the firms' performance is subject to macroeconomic conditions as well as industryspecific environment. To eliminate these biases, the adopting firms' performance is also compared against their matched-pair firms' performance within the same industry with an equivalent size. Findings of the comparative performance between the two groups are as reported in Table 6. 
Apart from net profit margin (NPM) and returns on equity (ROE), other performance measures such as operational profitability (operating profit margins), assets management efficiency (return on assets), growth performance (Tobin's Q) and firmrisk (debt over assets) do not show any signs of being statistically different from the overall industry performances (matchedpair firms). Even though NPM and ROE of adopting and non-adopting firms are significantly different, the values are still negative implying that the adopting firms' performance has not improved since the base year but fares better than the nonadopting firms.

Given the findings, there is no conclusive evidence of ESOS being an effective tool to mitigate agency problems and bring together the interest of the managers (majority shareholders) and that of the shareholders (minority shareholders). Although there is slight evidence of adopting firms faring better than their industry-sized matched-pairs, the measures are more focused on profitability than efficiency. The findings are similar to those reported by Yeo et al. (1999).

Table 5

Performance of ESOS Adopting Firms

\begin{tabular}{|c|c|c|c|c|}
\hline Measure of Performance & $\begin{array}{l}\text { Year }-1 \\
\text { to } \\
\text { Year } 0\end{array}$ & $\begin{array}{l}\text { Year }-1 \\
\text { to } \\
\text { Year } 1\end{array}$ & $\begin{array}{l}\text { Year -1 } \\
\text { to } \\
\text { Year } 2\end{array}$ & $\begin{array}{l}\text { Year }-1 \\
\text { to } \\
\text { Year } 3\end{array}$ \\
\hline \multicolumn{5}{|c|}{ Operating Profits Margin (OPM), Median year $-1=0.10$} \\
\hline Median Change Firms & -0.06 & -0.09 & -0.17 & -0.25 \\
\hline Asymp. Sig. (2-tailed) & 0.80 & 0.08 & 0.81 & 0.07 \\
\hline \multicolumn{5}{|c|}{ Net Profits Margin (NPM), Median year $-1=0.06$} \\
\hline Median Change Firms & -0.07 & -0.14 & -0.23 & -0.11 \\
\hline Asymp. Sig. (2-tailed) & 0.31 & 0.61 & 0.64 & 0.56 \\
\hline \multicolumn{5}{|c|}{ Returns on Asset (ROA), Median year $-1=0.65$} \\
\hline Median Change Firms & -0.05 & -0.12 & -0.15 & -0.25 \\
\hline Asymp. Sig. (2-tailed) & 0.00 & 0.00 & 0.00 & 0.00 \\
\hline \multicolumn{5}{|c|}{ Returns on Equity (ROE), Median year $-1=0.08$} \\
\hline Median Change Firms & -0.09 & 0.01 & -0.37 & -0.34 \\
\hline Asymp. Sig. (2-tailed) & 0.06 & 0.25 & 0.05 & 0.02 \\
\hline \multicolumn{5}{|l|}{ Tobins Q, Median year $-1=1.19$} \\
\hline Median Change Firms & 0.07 & 0.08 & 0.03 & 0.06 \\
\hline Asymp. Sig. (2-tailed) & 0.96 & 0.63 & 0.96 & 0.99 \\
\hline \multicolumn{5}{|l|}{ Debt $/$ Asset $(\mathrm{D} / \mathrm{A})$, Median year $-1=0.35$} \\
\hline Median Change Firms & 0.00 & 0.00 & -0.02 & 0.01 \\
\hline Asymp. Sig. (2-tailed) & 0.39 & 0.76 & 0.83 & 0.78 \\
\hline
\end{tabular}


Table 6

Comparative Performance between ESOS Adopting and Non-Adopting Firms

\begin{tabular}{|c|c|c|c|c|}
\hline Measure of Performance & $\begin{array}{l}\text { Year }-1 \\
\text { to } \\
\text { Year } 0\end{array}$ & $\begin{array}{l}\text { Year }-1 \\
\text { to } \\
\text { Year } 1\end{array}$ & $\begin{array}{l}\text { Year }-1 \\
\text { to } \\
\text { Year } 2\end{array}$ & $\begin{array}{l}\text { Year }-1 \\
\text { to } \\
\text { Year } 3\end{array}$ \\
\hline $\begin{array}{l}\text { Operating Profits Mgn. (OPM) } \\
\qquad \begin{array}{l}\text { Firm Median year }-1=0.10 \\
\text { Industry Adjusted Median year }-1=0.16\end{array}\end{array}$ & & & & \\
\hline Median Firms Change & -0.05 & -0.09 & -0.16 & -0.25 \\
\hline Median Industry Adjusted Change & -0.05 & -0.23 & -0.22 & -0.38 \\
\hline Asymp. Sig. (2-tailed) & 0.28 & 0.32 & 0.43 & 0.26 \\
\hline 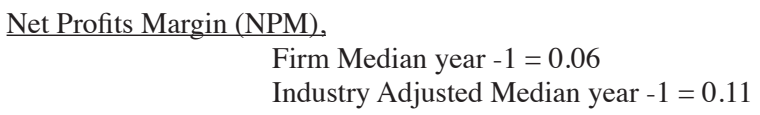 & & & & \\
\hline Median Firms Change & -0.07 & -0.14 & -0.22 & -0.10 \\
\hline Median Industry Adjusted Change & -0.05 & -0.30 & -0.44 & -0.60 \\
\hline Asymp. Sig. (2-tailed) & 0.34 & 0.04 & 0.01 & 0.00 \\
\hline $\begin{array}{l}\text { Returns on Asset (ROA), } \\
\quad \begin{array}{l}\text { Firm Median year }-1=0.65 \\
\text { Industry Adjusted Median year }-1=0.73\end{array}\end{array}$ & & & & \\
\hline Median Firms Change & -0.04 & -0.12 & -0.15 & -0.24 \\
\hline Median Industry Adjusted Change & -0.02 & -0.07 & -0.08 & -0.07 \\
\hline Asymp. Sig. (2-tailed) & 0.95 & 0.86 & 0.37 & 0.66 \\
\hline $\begin{array}{l}\text { Returns on Equity (ROE), } \\
\begin{array}{l}\text { Firm Median year }-1=0.08 \\
\text { Industry Adjusted Median year }-1=0.06\end{array}\end{array}$ & & & & \\
\hline Median Firms Change & -0.09 & 0.00 & -0.37 & -0.34 \\
\hline Median Industry Adjusted Change & -0.10 & -0.27 & -0.30 & -0.58 \\
\hline Asymp. Sig. (2-tailed) & 0.57 & 0.04 & 0.64 & 0.00 \\
\hline $\begin{array}{l}\text { Firm Median year }-1=1.19 \\
\text { Industry Adjusted Median year }-1=1.30\end{array}$ & & & & \\
\hline Median Firms Change & 0.07 & 0.07 & 0.03 & 0.06 \\
\hline Median Industry Adjusted Change & 0.02 & 0.01 & 0.03 & 0.02 \\
\hline Asymp. Sig. (2-tailed) & 0.37 & 0.51 & 0.29 & 0.29 \\
\hline $\begin{array}{ll}\text { Debt / Asset (D/A). } & \\
& \text { Firm Median year }-1=0.35 \\
& \text { Industry Adjusted Median year }-1=0.42\end{array}$ & & & & \\
\hline Median Firms Change & -0.00 & 0.00 & -0.01 & 0.01 \\
\hline Median Industry Adjusted Change & 0.02 & -0.00 & 0.02 & 0.00 \\
\hline Asymp. Sig. (2-tailed) & 0.34 & 0.51 & 0.49 & 0.70 \\
\hline
\end{tabular}




\section{Conclusion}

The theory of the firm and the agency theory postulate that managers acting as agents for the owners may pursue strategies that maximize their own utilities rather than that of the owners. By making managers become part of the owners, the interest of the managers can be aligned with those of the shareholders. Theoretically, ESOS adoption could help mitigate agency problems especially in the setting where the ownership of the firm is dispersed (Type I problem). Since there are no dominant shareholders, managers who are also owners of the firm would work harder and would bear part of the consequences of their own decisions. Previous studies have found significant relationship between executive compensations and firm's performance although the more recent literature cast some doubts over the effectiveness of equitybased compensation in mitigating agency problems.

The major assumption in these studies is that the agency problem is between the managers and the dispersed shareholders (Type 1 agency problem). The same set of assumptions cannot be extended to developing countries or emerging markets where an insider-system of corporate governance with high level of ownership concentration, cross-holdings and significant participation of owners in management are apparent (Claessens, Djankov \& Lang, 2000; Lemmons \& Lins, 2001; Mitton, 2002). Since managers are part of the controlling shareholders, the agency problems as reported in underdeveloped countries do not exist in the same manner. Instead, the divergence of interests exists between the majority and the minority shareholders (Type II agency problem). Rewarding managers who are already controlling owners through ESOS may not help solve the agency problems but instead could be viewed as a tool to expropriate wealth from the firm.

Findings from this study suggest that the usual determinants for adopting ESOS as reasoned in the Western literature do not seem to hold in a developing- country setting. ESOS is not being adopted to 'push' managers to work harder (i.e. increase profitability) as the relationship between the extent of income compared to the target and likelihood of ESOS adoption is negative. The practice of ESOS adoption is also prevalent among family-owned firms than any other types of firms. Whilst the significance of firmsize growth may give the impression that shareholders are taking proactive measures to align the managers' and the shareholders' interests, the sudden jump in firm-size growth over a short period (between a year after adoption and the adoption year) does raise concern if such numbers are 'massaged' given the long process of ESOS adoption. The growth of firm-size could have been 'planned' so that its increase can be used to justify the decision to adopt ESOS.

The effectiveness of ESOS in aligning the interest of the managers/controlling shareholders and the minority shareholders can be gauged by the extent of improvement in the performance experienced after the ESOS adoption. Results from internal performance do not reveal any increase in performance upon the adoption of ESOS. Similarly, performance against industry and size-matched pair do not show significant differences between the two groups except for slightly better performance though still not as good as the performance before ESOS adoption.

\section{References}

Barber, B., \& Lyon, J. (1996). Detecting abnormal operating performance: The empirical power and specification of 
test-statistics. Journal of Financial Economics, 41, 351 - 399.

Capulong, M. V., Edwards, D., Webb, D., \& Zhuang, Z. (2000). Corporate governance and finance in East Asia: A study of Indonesia, Republic of Korea, Malaysia, Philippines and Thailand: Vol.1 (A consolidated report). Asian Development Bank.

Claessens, S., Djankov, S., \& Lang, L. (2000). The separation of ownership and control in East Asian corporations. Retrieved from http://ssrn.com/

Choe, C. (1999). Executive stock options and investment choice. La Trobe University, School of Business Working Paper No. A99.11. Retrieved from http://ssrn.com/

Core, J., \& Guay, W. (2001). Stock option plans for non-executive employees. Journal of Financial Economics , 69, 253-287.

Core, J., \& Larcker, D. (2002). Performance consequences of mandatory increases in executive stock ownership. Retrieved from http://ssrn.com/

Coughlan, A., \& Schmidt, R. (1985). Executive compensation, management turnover, and firm performance: An empirical investigation. Journal of Accounting and Economics, 7(1-3), $43-66$.

Ding D. K., \& Sun, Q. (2001). Causes and effects of employee stock option plans: Evidence from Singapore. Pacific-Basin Finance Journal, 9, 563-598.

Fama, E., \& Jensen, M. (1983). Agency problems and residual claims. Journal of Law and Economics, 26, 327-349.

Fama, E. (1980). Agency problems and the theory of the firm. Journal of Political Economy, 88, 288-307.

Haniffa, R., \& Hudaib, M. (2006). Corporate governance structure and performances of Malaysia listed firms. Journal of Business Finance and Accounting, 1-29.

Hartzell, J. C., \& Starks, L. T. (2003). Institutional investors and executive compensation. Working Paper, New York University Stern School of Business.

Hillegeist, S. A., \& Penalva, F. (2004). Stock option incentives and firm performance. Retrieved from http:// ssrn.com/

Himmelberg, P., Hubbard, R., \& Palia, D. (1999). Understanding the determinants of managerial ownership and the link between ownership and performance. NBER Working Paper No. W7209. Retrieved from http:// ssrn.com/

Ittner, D., Lambert, A., \& Larcker, F. (2003). The structure and performance consequences of equity grants to employees of new economy firms. Journal of Accounting and Economics, 34, 89-127.

Jain, B. A., \& Kini, O. (1994). The postissue operating performance of IPO firms. The Journal of Finance, 49(5), $1699-1726$.

Jensen, M. C., \& Meckling, W. H. (1976). Theory of the firm: Managerial behavior, agency costs, and ownership structure. Journal of Financial Economics, 3(4), 306360.

Khatri, Y., Leruth, L., \& Piesse, J. (2002). Corporate performance and governance in Malaysia, IMF Working Paper WP/02/152, International Monetary Fund.

Lemmon, M. L., \& Lins, K.V. (2001). Ownership structure, corporate governance, and firm value: Evidence from the East Asian financial crisis. 3rdAnnual Financial Market Development Conference, 
Hong Kong 2001. Retrieved from http://ssrn.com/

Lewellen, W. G., \& Huntsman, B. (1970). Managerial pay and corporate performance. American Economic Review, 60, 710-720.

Matsunaga, S. R. (1995). The effects of financial reporting costs on the use of employee stock options. Accounting Review, 70, 1-26.

McConnell, J., \& Servaes, H. (1995). Equity ownership and the two faces of debt, Journal of Financial Economics, 39, 131-157.

Mehran, H. (1995). Executive compensation structure, ownership and firm performance. Journal of Financial Economics, 38, 163-184.

Mitton, T. (2002). Corporate governance and dividend policy in emerging markets. Emerging Markets Review, 5, 409 426.

Morck, R., Shleifer A., \& Vishny, R.W. (1988). Management ownership and market valuation: An empirical analysis. Journal of Financial Economics, 20, 293-315.

Murphy, K. J. (1999). Executive compensation. In Olrey Ashenfilter and David Card (Eds.). Handbook of Labor Economics, 3, North Holland.

Murphy,K.J.(1985).Corporate performance and managerial remuneration:
An empirical analysis. Journal of Accounting and Economics, 7, 11-42.

Parthasarathy, A., Bhattacherjee, D., \& Menon, K. (2006). Executive compensation, firm performance and corporate governance: An empirical analysis. Retrieved from http://ssrn. com/

Pugh, W. N., Oswald, S. L., \& Jahera, J. S. (2000). Managerial and Decision Economics. 21(5), p. 167.

Suret, J. M., Morill, C., \& Morill, J. (1997). Availability and accuracy of accounting and financial data in emerging market: The case of Malaysia. CIRANO Working Paper 97s-18.

Teoh, S. H., Welch, I., \& Wong, T. J. (1998). Earnings management and the underperformance of seasoned equity offerings. Journal of Financial Economics, 50, 63-99.

Yeo, G. H., Chen, S., Ho, K. W., \& Lee, C. (1999). Effects of executives share option plans on shareholder wealth and firm performance: The Singapore evidence. The Financial Review, 34, $1-20$.

Yermack, D. (1995). Do corporations award CEO stock options effectively? Journal of Financial Economics, 39, 